\title{
Faktor Risiko Penderita Prolapsus Organ Panggul terhadap Hiatus Genitalis, Panjang Total Vagina, dan Perineal Body
}

\author{
Benny Hasan Purwara, Edwin Armawan, R. M. Sonny Sasotya, Eppy Darmadi Achmad \\ Subbagian Uroginekologi dan Rekonstruksi Panggul Perempuan, Departemen Obstetri Ginekologi \\ Fakultas Kedokteran Universitas Padjadjaran/Rumah Sakit Dr. Hasan Sadikin Bandung
}

\begin{abstract}
Abstrak
Prolapsus organ panggul (POP) merupakan kondisi yang umum pada perempuan usia lanjut. Keluhannya bersifat prolapsus organ panggul (POP) merupakan kondisi umum bersifat progresif pada perempuan usia lanjut. Saat ini belum ada laporan mengenai hubungan antara komponen faktor risiko dan anatomi. Penelitian ini untuk mengetahui faktor risiko klinis POP serta pengaruhnya pada komponen anatomi penentu tahapan klinis kelainan tersebut. Penelitian dilakukan di Departemen Obstetri dan Ginekologi Fakultas Kedokteran Unpad/Rumah Sakit Dr. Hasan Sadikin Bandung periode Desember 2009-Mei 2010. Limapuluh dua pasien POP dibagi menjadi dua kelompok yaitu 30 subjek POP tingkat III dan 22 POP tingkat I-II. POP berasosiasi signifikan dengan usia, paritas, menopause, serta TSH. Usia $\geq 50$ tahun $(\mathrm{OR}=0,08 ; 95 \% \mathrm{IK}=0,018-0,333$ versus $<50$ tahun), paritas $\geq 3$ $(\mathrm{OR}=5,56 ; 95 \% \mathrm{IK}=0,02-0,55$ versus paritas $<3)$, dan status menopause $(\mathrm{OR}=5,14 ; 95 \% \mathrm{IK}=1,18-22,49$ versus tidak menopause). Korelasi positif signifikan panjang hiatus genitalis $(\mathrm{HG})$ dengan usia $(\mathrm{r}=0,656)$ dan paritas $(\mathrm{r}=0,539)$. Ukuran perineal body $(\mathrm{PB})$ korelasi negatif signifikan dengan usia $(\mathrm{r}=-0,298)$ dan paritas $(\mathrm{r}=-0,335)$. Kelompok menopause menunjukkan peningkatan panjang HG dan penurunan ukuran PB yang signifikan. Panjang PB meningkat signifikan pada kelompok yang menerima TSH. Hubungan yang signifikan antara panjang total vagina (PTV) dan faktor-faktor risiko hanya menemukan pemendekan PTV signifikan pada usia $>50$ tahun. Simpulan, usia, paritas, dan menopause merupakan faktor risiko kemungkinan POP serta mempunyai korelasi dengan panjang GH dan PB dan progresivitas POP. [MKB. 2014;46(1):57-60]
\end{abstract}

Kata kunci: Hiatus genitalis, panjang total vagina, perineal body, prolapsus organ panggul

\section{Risk Factors for Patients with Pelvic Organ Prolapse on Hiatus Genitalis, Total Vaginal Length, and Perineal Body}

\begin{abstract}
Pelvic organ prolapse (POP) is a common and progressive condition in elderly women. Currently, there are no report regarding the relationship between risk factor and anatomical components. This research was to identify risk factors and its influence on the POP clinical anatomy component determining clinical stages of this disorder. The study was conducted at the Department of Obstetrics and Gynaecology, Faculty of Medicine Universitas Padjadjaran/Dr. Hasan Sadikin General Hospital Bandung during the period of December 2009-May 2010. Fiftytwo POP patients were participated, 30 subjects were in grade III and 22 subjects were in grade I-II. Found a significant association between age, parity, menopause, and hormone replacement therapy (HRT) and the incidence POP. Age $>50$ years $(\mathrm{OR}=0.08,95 \% \mathrm{CI}=0.018$ to 0.333 versus $<50$ years), parity $>3(\mathrm{OR}=5.56,95 \% \mathrm{C} 1=0.02$ to 0.55 versus parity $<3)$, and menopausal status $(\mathrm{OR}=5.14,95 \% \mathrm{CI}=1.18$ to 22.59 versus not menopausal). Long hiatus genetalis $(\mathrm{HG})$ had a significant positive correlation to age $(\mathrm{r}=0.656)$, while $\mathrm{HG}$ had a significant positive correlation to parity $(\mathrm{r}=0.539)$. Size of the perineal body $(\mathrm{PB})$ showed a significant negative correlation with age $(r=-0.298)$ and parity $(r=-0.335)$. Menopausal group showed significant increase in HG length and decrease in size of the PB compared to the premenopausal group. The PB length increased significantly in those receiving HRT $(p=0.018)$. Significant relationship between total length of the vagina $(P T V)$ and the risk factors was only found in the form of significant shortening of PTV at aged $>50$ years. In conclusion, age, parity, and menopause are risk factors for POP probability and has a correlation with HG length, PB and progression of POP. [MKB. 2014;46(1):57-60]
\end{abstract}

Key words: Genital hiatus, pelvic organ prolapse, perinael body, total vaginal length

Korespondensi: Benny Hasan Purwara, dr., Sp.OG(K), Departemen Obstetri dan Ginekologi Fakultas Kedokteran Universitas Padjadjaran/Rumah Sakit Dr. Hasan Sadikin Jalan Pasteur No. 38 Bandung, mobile 08122011778, e-mail bennyhp3042@ gmail.com 


\section{Pendahuluan}

Prolapsus organ panggul (POP) adalah turunnya visera pelvis (uterus, kandung kemih, uretra, dan rekrum) dari posisi normal. Kondisi tersebut umum terjadi pada perempuan usia lanjut dengan insidensi sekitar $39,8 \% .{ }^{1}$ Life time risk seorang perempuan untuk menjalani operasi POP atau inkontinensia diperkirakan yaitu $11 \%{ }^{1,2}$ Prolapsus organ panggul disebabkan oleh karena kelemahan dasar panggul. Hilangnya daya dukung yang terbentuk dari interaksi dinamis tulang panggul, jaringan ikat endopelvis, dan otot dasar panggul, dapat memicu POP. ${ }^{3,4}$ Proses ini berlangsung secara perlahan dan memerlukan waktu beberapa tahun. Keluhan dirasakan penderita umumnya bersifat perlahan tetapi progresif sesuai dengan bertambah beratnya penurunan visera pelvis yang terjadi, sehingga dapat dan menurunkan kualitas hidup. Gejala akibat POP antara lain adalah nyeri perut bagian bawah, konstipasi, dan gangguan berkemih.

Beberapa faktor risiko klinis sudah diketahui, antara lain usia, pascamenopause, persalinan per vaginam, trauma pada persalinan, dan keadaan klinis yang dapat meningkatkan tekanan intraabdominal menahun. Beberapa faktor lain diduga berpengaruh, yaitu genetik, merokok, defisiensi estrogen, dan juga penyakit kelainan kolagen..$^{5-7}$ Insidensi dan prevalensi POP di suatu daerah atau komunitas ras tertentu dapat berbeda, hal tersebut disebabkan perbedaan interaksi dinamis berbagai faktor risiko disertai pengaruh perbedaan ras. ${ }^{8}$ Selama ini laporan penelitian hanya menunjukkan pengaruh faktor risiko terhadap insidensi POP secara umum, tetapi hubungan antara gabungan komponen faktor risiko dan komponen anatomis POP (ukuran hiatus genitalis, panjang total vagina, ukuran perineal body) yang belum jelas diketahui. Karena itu, tujuan penelitian ini untuk mengevaluasi faktor risiko apa saja yang terdapat pada penderita POP di RS Dr. Hasan Sadikin Bandung, serta bagaimana hubungan faktor risiko klinis tersebut dengan komponen anatomi POP.

\section{Metode}

Subjek penelitian ini terdiri atas 52 pasien Klinik Ginekologi/Uroginekologi RS Dr. Hasan Sadikin Bandung bulan Desember 2009 hingga Mei 2010. Data dikumpulkan retrospektif dari rekam medik dan wawancara langsung. Data dicatat di dalam formulir khusus yang disediakan untuk penelitian ini. Subjek terbagi dua kelompok, terdiri atas kelompok POP stadium III atau lebih dan kelompok POP stadium < III (derajat POP ditentukan berdasarkan nilai skoring kuantifikasi
ICS, yaitu POP-Q) ${ }^{3}$. Anamnesis serta semua riwayat kelainan ginekologi dan juga pemeriksaan fisis ginekologi dicatat. Pemeriksaan panggul dilakukan dalam posisi litotomi, sedangkan pada derajat POP diukur dengan bantuan tes valsava. Usia, paritas, indeks massa tubuh dihitung, serta riwayat pemakaian terapi hormon reproduksi atau terapi sulih hormon ditanyakan dan dicatat. Student's t-test digunakan untuk membandingkan variabel kontinu dan tes $\chi^{2}$ dipergunakan untuk membandingkan data kategorik. Uji eksak Fisher dilakukan ketika asumsi untuk distribusi $\chi^{2}$ tidak dipenuhi. Analisis regresi logistik dipergunakan untuk mengetahui faktor risiko yang independen terkait dengan POP. Hubungan antara faktor risiko dan derajat POP atau kompartemen lain (pengukuran hiatus genitalis, perineal body, dan panjang total vagina) dihitung menggunakan $\chi^{2}$, Fisher, student's t-test, dan Uji Korelasi Pearson yang sesuai; nilai kemaknaan statistik yang digunakan adalah $\mathrm{p}<0,05$. Perhitungan statistik menggunakan bantuan Statistical Product and Service Solutions (SPSS) 16.

\section{Hasil}

Subjek penelitian ini terdiri atas dua kelompok, yaitu 30 subjek termasuk dalam kelompok POP stadium $\geq$ III dan 22 subjek dalam kelompok POP stadium < III (kontrol). Faktor risiko usia, paritas, dan status menopause mempunyai perbedaan yang signifikan antara kedua kelompok $(p<0,05)$. Analisis multivariat menunjukkan usia lebih dari 50 tahun $(\mathrm{OR}=0,08 ; 95 \% \mathrm{IK}=0,018-0,333$ versus $\geq 50, p=0,000)$, paritas nilai $\geq 3(\mathrm{OR}=5,56 ; 95 \%$ $\mathrm{IK}=0,02-0,55$ versus $<3 ; \mathrm{p}<0,001)$, dan status menopause $\quad(\mathrm{OR}=5,14 ; 95 \% \quad \mathrm{IK}=1,18-22,49$ versus tidak menopause, $\mathrm{p}<0,021)$ merupakan faktor risiko signifikan untuk POP.

Dilakukan perhitungan hubungan faktor risiko dengan komponen lainnya seperti hiatus genital (HG), perineal body (PB), dan juga panjang total vagina (PTV) subjek kelompok POP. Panjang HG mempunyai korelasi positif yang signifikan dengan kekuatan korelasi yang kuat terhadap usia $(\mathrm{p}=0,000 ; \mathrm{r}=0,656)$; sedangkan $\mathrm{HG}$ mempunyai korelasi positif yang signifikan dengan kekuatan korelasi yang sedang terhadap paritas $(\mathrm{p}=0,004$; $\mathrm{r}=0,539)$. Ukuran $\mathrm{PB}$ memperlihatkan korelasi negatif signifikan dengan usia $(r=-0,298 ; \mathrm{p}<0,05)$ dan juga paritas $(r=-0,335 ; \mathrm{p}<0,05)$. Kelompok menopause menunjukkan peningkatan signifikan panjang $\mathrm{HG}(\mathrm{p}<0,05)$ dan penurunan ukuran $\mathrm{PB}$ $(p<0,05)$ apabila dibandingkan dengan kelompok premenopause. Panjang PB meningkat signifikan pada subjek yang menerima TSH ( $\mathrm{p}=0,018$; Tabel 2). Hubungan signifikan pemendekan antara PTV 
Benny Hasan.: Faktor Risiko Penderita Prolapsus Organ Panggul terhadap Hiatus Genitalis, Panjang Total Vagina

Tabel 1 Hubungan Karakteristik Penderita terhadap Prolaps Organ Panggul

\begin{tabular}{lccc}
\hline & $\begin{array}{c}\text { POP Stadium }<\text { III } \\
(\mathbf{n = 2 2})\end{array}$ & $\begin{array}{c}\text { POP Stadium } \geq \text { III } \\
(\mathbf{n = 3 0 )}\end{array}$ & Nilai $\boldsymbol{\rho}$ \\
\hline Usia (tahun) & $47,47+11,40$ & $64,17+9,85$ & 0,000 \\
Indeks massa tubuh $\left(\mathrm{kg} / \mathrm{m}^{2}\right)$ & $21,93+1,05$ & $21,86+1,06$ & 0,829 \\
Paritas & $3,00+1,02$ & $4,27+1,36$ & 0,001 \\
Menopause & & & \\
$\quad$ Ya & $14(26,9 \%)$ & $27(51,9 \%)$ & 0,021 \\
$\quad$ Tidak & $8(15,4 \%)$ & $3(5,8 \%)$ & \\
TSH & & & \\
$\quad$ Ya & $17(32,7 \%)$ & $24(46,2 \%)$ & 0,812 \\
$\quad$ Tidak & $5(9,6 \%)$ & $6(11,5 \%)$ & \\
\hline
\end{tabular}

Keterangan: Data dipresentasikan sebagai mean-SD atau dengan persentase. Perhitungan signifikansi menggunakan student's t test, chi-kuadrat, $\mathrm{p}<0,05$

dan usia $\geq 50$ tahun $(\mathrm{p}<0,05)$.

\section{Pembahasan}

Beberapa dekade yang telah lalu, sebagian besar penderita POP jarang datang mencari bantuan medis, tetapi dalam satu dekade terakhir jumlah penderita yang datang ke klinik ginekologi cukup meningkat seiring dengan peningkatan perawatan medis dan juga tingkat sosioekonomi masyarakat Indonesia secara umum.

Pada tahun 1996 the International Continence Society telah mendefinisikan sistem baru untuk kuantifikasi POP. Sistem POP-Q baru yang telah dipublikasikan ternyata memberikan kontribusi yang besar terhadap kemajuan dalam mempelajari epidemiologi serta patofisiologi klinis POP. Hal ini dikarenakan para peneliti dimungkinkan untuk dapat melaporkan temuan dalam mode standar seluruh tempat di dunia. Sistem baru ini memiliki kehandalan intraobserver dan juga interobserver yang cukup baik. ${ }^{3,5}$ Di negara Indonesia masih sulit menemukan angka prevalensi serta insidensi yang dapat mewakili kejadian POP secara umum. Para klinisi belum melakukan penelusuran lebih lanjut karakteristik epidemiologi berdasarkan population base, angka yang telah ada mewakili kejadian POP di beberapa rumah sakit pendidikan tertentu. Menurut Weber ${ }^{8}$ faktor risiko potensial

Tabel 2 Hubungan antara Faktor Risiko POP dan Beberapa Pengukuran POPQ

\begin{tabular}{|c|c|c|c|c|c|c|}
\hline & PB (cm) & Nilai p & HG (cm) & Nilai p & PTV (cm) & Nilai $p$ \\
\hline \multicolumn{7}{|c|}{ Usia (tahun) } \\
\hline$<50$ & $2,48+0,46$ & \multirow{2}{*}{0,029} & $4,68+0,43$ & \multirow[t]{2}{*}{0.000} & $6,90+0,74$ & \multirow{2}{*}{0,027} \\
\hline$\geq 50$ & $2,16+0,50$ & & $5,34+0,33$ & & $6,39+0,73$ & \\
\hline \multicolumn{7}{|l|}{ Paritas } \\
\hline$<3$ & $2,59+0,44$ & \multirow{2}{*}{0,015} & $4,66+0,56$ & \multirow[t]{2}{*}{0,004} & $6,94+0,79$ & \multirow{2}{*}{0,080} \\
\hline$\geq 3$ & $2,17+0,49$ & & $5,27+0,35$ & & $6,44+0,73$ & \\
\hline \multicolumn{7}{|c|}{ Menopause } \\
\hline $\mathrm{Ya}$ & $2,02+0,36$ & \multirow{2}{*}{0,038} & $5,02+0,45$ & \multirow[t]{2}{*}{0.000} & $6,38+0,64$ & \multirow{2}{*}{0,382} \\
\hline Tidak & $2,32+0,53$ & & $5,58+0,20$ & & $6,59+0,80$ & \\
\hline \multicolumn{7}{|l|}{$\mathrm{TSH}$} \\
\hline $\mathrm{Ya}$ & $2,34+0,50$ & \multirow{2}{*}{0,018} & $5,10+0,50$ & \multirow{2}{*}{0,213} & $6,51+0,81$ & \multirow{2}{*}{0,871} \\
\hline Tidak & $1,96+0,41$ & & $5,26+0,32$ & & $6,55+0,76$ & \\
\hline
\end{tabular}

Keterangan: Data dipresentasikan sebagai mean-SD atau dengan persentase , $\mathrm{PB}=$ perineal body; $\mathrm{HG}=$ hiatus genitalis; $\mathrm{PTV}=$ panjang total vagina. Perhitunga signifikansi menggunakan student's $t$-test, $\mathrm{p}<0,05$ 
untuk POP dikategorikan sebagai predisposisi atau peristiwa kompensasi yang terjadi secara kronik. Peneliti lainnya juga menemukan banyak faktor risiko obstetrik yang berpengaruh pada prolaps organ panggul. Penelusuran dan pengungkapan patofisiologi serta etiologi POP masih terbuka lebar karena masih belum diketahuinya kedua hal tersebut.

Dalam penelitian ini, usia lebih dari 50 tahun, paritas lebih dari tiga, dan juga status menopause merupakan faktor risiko independen untuk gejala POP. Terapi sulih hormon dan BMI tampaknya tidak mempunyai peran yang signifikan terhadap kejadian POP. Hal ini sesuai dengan penelitian yang dilakukan Swift dkk. ${ }^{6}$ yang melaporkan sulit untuk merekomendasikan terapi sulih hormon untuk dapat mencegah POP. Penelitian Nygaard dkk. ${ }^{5}$ menghasilkan keadaan yang sama, yaitu POP tidak berkaitan dengan estrogen terkonjugasi dan juga pengobatan medroksiprogesteron jika dibandingkan dengan plasebo.

Penelitian ini memperlihatkan bahwa usia, paritas, dan status menopause mempunyai kaitan dengan tahapan pada POP. Usia pascamenopause mempunyai total kadar kolagen yang kurang, penurunan kelarutan kolagen, serta peningkatan pergantiankolagen, keadaantersebutberkontribusi terhadap perkembangan dan kemajuan POP bila dibandingkan dengan usia reproduktif. Lang dkk. ${ }^{9}$ melaporkan bahwa estradiol serum dan kadar reseptor estrogen (ER) di ligamen sakrouterina jauh lebih rendah pada POP usia premenopause dibandingkan dengan kelompok kontrol. Oleh karena itu, kekurangan estrogen dan reseptornya mungkin berperan di dalam POP premenopause. Beberapa keterbatasan penelitian ini, yaitu lama terapi hormonal terhadap perempuan menopause tidak diketahui.

Delancey ${ }^{10}$ dalam penelitiannya melaporkan ukuran hiatus urogenital lebih besar pada wanita dengan prolaps dibandingkan dengan kelompok kontrol dan beberapa yang gagal setelah dilakukan operasi perbaikan prolaps berhubungan dengan ukuran hiatus. Keadaan tersebut diketahui bahwa HG yang melebar mungkin memiliki peran dalam perkembangan POP serta berhubungan dengan prolaps. Oleh karena itu, sistem levator yang melemah karena cedera otot dan $\mathrm{HG}$ yang melebar menyebabkan progresifnya perkembangan POP. Penelitian ini tidak hanya mengidentifikasi faktor risiko POP, tetapi juga mengevaluasi pengaruh faktor risiko pada beberapa parameter komponen POP.

Sebagai simpulan, usia, paritas, dan menopause merupakan faktor risiko yang mungkin berperan pada progresivitas tahapan POP. Hal ini terkait dengan ukuran hiatus genitalis dan perineal body. Faktor risiko ini, bersama dengan terapi hormon secara signifikan berkorelasi terhadap progresivitas tahapan POP.

\section{Daftar Pustaka}

1. Hendrix SL, Clark A. Pelvic organ prolapse in the women's health initiative: gravity and gravidity. Am J Obstet Gynecol. 2002; 186(6):1160-6.

2. Olsen AL, Berstrom VO, Clark A. Epidemiology of surgically managed pelvic organ prolapse and urinary incontinence. Obstet Gynecol. 1997;89:501-6.

3. Jelovsek JE, Maher C, Barber MD. Pelvic organ prolapse. Lancet. 2007;369:1027-38.

4. Petros PP. The female pelvic floor function, dysfunction and management according to the integral theory. Edisi ke-2. Berlin: Springer Medizin Verlag Heidelberg; 2007.

5. Nygaard I, Bradley C, Brandt D. Pelvic organ prolapse in older women: prevalence and risk factors. Obstet Gynecol. 2004;104:489-9.

6. Swift SE, O'Boyle AL, Woodman PJ, O'Boyle JD, Davis GD. Pelvic organ support in nulliparous pregnant and nonpregnant women: a case control study. Am J Obstet Gynecol. 2002;187:99-102.

7. Handa VL. Physiology and pathophysiology of disorders of pelvic support. Dalam: Bent AE, Cundiff GW, Swift SE, editor. Ostergard's urogynecology and pelvic floor dysfunction. Edisi ke-6. Philadelphia: Wolters Kluwer Lippincot Williams \& Wilkins; 2008. hlm. 417-21.

8. Weber A. Epidemiology and psychosocial impact of pelvic floor disorders. Dalam: Siddighi S, Hardesty JS, penyunting. Urogynecology and recontructive pelvic surgery. Edisi ke-3. New York: McGrawHill; 2006. hlm. 44-52.

9. Lang J, Zhu L, Sun Z, Chen J. Estrogen level and estrogen receptors in patient with stress urinary incontinence and pelvic organ prolapse. Int J Obstet Gynecol. 2003;80:359.

10. DeLancey JO. Structural support of the urethra as it relates to stress incontinence: the hammock hypothesis. Am J Obstet Gynecol. 1994;170:1713-72. 